\title{
Hubungan Asupan Zink, Magnesium, dan Serat dengan Kadar Gula Darah Puasa Pasien Diabetes Mellitus Tipe 2 di RS PKU Muhammadiyah Temanggung
}

\author{
Efina Amanda ${ }^{1}$, Salsa Bening ${ }^{2}$ \\ ${ }^{\mathbf{1 , 2}}$ Program Studi S1 Gizi Fakultas Ilmu Keperawatan dan Kesehatan \\ Universitas Muhammadiyah Semarang \\ efina.amanda96@gmail.com,b3n.salsa@gmail.com
}

\begin{abstract}
Diabetes Mellitus (DM) type 2 occurs because of insulin resistance, on of the contributing factors is the lack of intake of micronutrients (zinc and magnesium) and macro (fiber). The prevalence of DM in Temanggung is 1,6\%. There are 45 patients suffering from type 2 diabetes at PKU Muhammadiyah Hospital in Temanggung which have zinc, magnesium, and fiber intake below normal (deficit). The study aims to analyze the relationship of zinc, magnesium, and fiber intake with fasting blood sugar levels at PKU Muhammadiyah Hospital in Temanggung.

The research is a cross sectional design with 45 responden taken with purposive sampling technique. Statistical analysis using kolmogorov smirnov normality test was tested using the spearman correlation test.

Data collection of zinc, magnesium, and fiber intake using the $2 \times 24$ hour recall and FFQ form while the blood sugar level data is obtained from the patient's medical record book.

The result showed that there was a relationship between zinc intake to fasting sugar levels of patients $(p=0,000)$, there was a correlation between magnesium intake to fasting blood sugar levels in patients $(p=0,000)$.

There is a relationship between zinc, magnesium, and fiber intake to fasting blood sugar levels.
\end{abstract}

Keywords: Zink Intake, Magnesium Intake, Fiber Intake, Fasting Blood Sugar Level, Type 2 Diabetes Mellitus

\section{PENDAHULUAN}

Diabetes Mellitus (DM) adalah keseluruhan gangguan metabolik ditandaidengan kadar gula darah diatas standar sehingga dapat mempengaruhi metabolisme zat gizi karbohidrat lemak dan protein disertai etiologi multi faktor (Gibney J.M et al, 2009). American Diabetes
Association (2015) menyebutkan bahwa DM adalah kelompok penyakit metabolik yang salah satu tandanya adalah adanya kondisi hiperglikemia karena gangguan sekresi insulin, kerja insulin, atau keduanya.

Kadar gula darah puasa dapat dikatakan DM apabila melebihi 126 mg/dl (PERKENI, 2015). Meskipun kadar gula 
darah tinggi, pemisahan protein dan lemak menjadi gula di hati tidak dapat dihambat dan akhirnya kadar gula darah meningkat.

Penelitian Albertus (2000) mengungkapkan bahwa pasien DM tipe 2 memiliki kadar zink yang lebih rendah secara signifikan jika dibandingkan dengan orang normal. Zink adalah zat gizi mikro yang memiliki peran penting untuk modulasi sistem imun (Akhuemukhan dkk, 2013). Kemampuan tubuh untuk mensintesis dan mengeluarkan insulin dipengaruhi oleh zink dalam tubuh, karena zink ikut serta dalam mekanisme regulasi dan sintesis reseptor insulin (Wierensperger dkk., 2010). Dalam penelitian Kartika (2016) menyatakan bahwa jumlah suplementasi 30 hari dengan dosis 5 $\mathrm{mg} / \mathrm{kg}$ BB memiliki hasil yang lebih baik jika dibandingkan dengan dosis $3 \mathrm{mg} / \mathrm{kg}$ BB terhadap kadar gula darah.

Penelitian Faraditha (2014) menyatakan $46 \%$ pasien DM tipe 2 memiliki asupan magnesium yang defisit, hasil penelitian serupa yang dilakukan Albertus (2000) menunjukkan bahwa pasien dengan DM tipe 2 memiliki kadar magnesium yang lebih rendah secara signifikan jika dibandingkan dengan orang normal. Magnesium adalah zat gizi mikro penting pada berbagai enzim dan mineral terbanyak kedua di intrasel. Gula akan lebih mudah masuk ke dalam sel karena magnesium sekaligus magnesium akan berperan sebagai kofaktor berbagai enzim untuk proses oksidasi gula. Terdapat penelitian yang telah dilakukan kepada hewan coba tikus yang menunjukkan diet rendah magnesium akan mengarah pada gangguan mekanisme sekresi insulin sedangkan kejadian DM yang menurun mampu diatasi dengan suplementasi magneisum (Larsson, 2007). DM dan beberapa penyakit lain telah dikaitkan denga perubahan distribusi magnesium dalam tubuh. Asupan magnesium dengan kadar cukup terutama pada pasien dengan DM dapat dihubungkan dengan salah satu perannya yaitu penjagaan homeostatis gula darah dengan aktivasi faktor-faktor yang ikut serta dalam proses sensitivitas insulin (Sales dkk, 2011). Kurangnya kadar magnesium dalam tubuh dapat mengurangi aktivitas tirosin kinase dalam reseptor insulin yang akan berdampak pada turunnya sensitivitas insulin (Song dkk, 2013). Penelitian yang dilakukan Anggun (2014) mengenai hubungan asupan magnesium dengan kadar gula darah pasien diabetes mellitus tipe 2 menunjukkan terdapat hubungan yang signifikan. 
Penelitian Witasari (2009) menunjukkan bahwa 100\% responden yang merupakan penderita DM tipe 2 memiliki asupan serat yang buruk. Kadar gula darah puasa juga dipengaruhi oleh asupan serat, pengaruh serat terhadap kadar gula darah puasa yaitu memperbaiki penanganan gua dalam tubuh dengan cara emperlambat absorpsi karbohidrat (Achadi, 2007). Anjuran serat untuk penderita diabetes yaitu 20-35 gram/hari yang berasal dari berbagai sumber makanan (PERKENI, 2015). Hasil penelitian yang dilakukan Bintanah (2012) di Rumah Sakit Roemani Semarang menyatakan bahwa serat terdapat hubungan yang erat dengan kadar gula darah.

Prediksi World Health Organization (WHO) menyatakan adanya kenaikan jumlah penderita diabetes yang cukup besar yaitu dari 8,4 juta jiwa pada tahun 2000 meningkat menjadi 21,3 juta jiwa pada tahun 2030 dengan pertumbuhan 152\% (WHO, 2006). Riskesdas tahun 2013 melakukan survey dengan wawancara menghitung proporsi DM pada umur 15 tahun keatas. Hasil wawancara menyatakan bahwa proporsi DM pada Riskesdas 2013 lebih tinggi hampir dua kali lipat dibandingkan tahun 2007. Proporsi DM di Indonesia pada Riskesdas 2013 sebesar 6,9\%, prevalensi DM di Provinsi Jawa
Tengah 1,9\% sedangkan pada Kabupaten Temanggung prevalensi DM sebesar 1,6\%. Data RS PKU Muhammadiyah Temanggung menyatakan pada tahun 2018 DM tipe 2 berada di peringkat 11 dari 15 besar penyakit yang paling sering ditemukan dan data bulan januari hingga november menunjukkan jumlah kasus DM tipe 2 sebanyak 738 pasien rawat inap dan 322 pada pasien rawat jalan. Tahun 2017 menuju 2018, pasien rawat inap mengalami kenaikam sebesar $45 \%$ atau sekitar 147 orang.

Berdasarkan uraian yang telah dijelaskan mengenai tingginya kasus DM dan terdapat zat gizi mikro dan makro yang mampu mempengaruhi kadar gula darah puasa, serta pada beberapa penelitian terdahulu belum pernah meneliti beberapa zat gizi mikro dan makro secara bersamaan, maka peneliti ingin menganalisis Hubungan Asupan Zink, Magnesium, dan Serat dengan Kadar Gula Darah Puasa Diabetes Mellitus Tipe 2 di RS PKU Muhammadiyah Temanggung.

Rumusan masalah dalam penelitian ini yaitu apakah terdapat hubungan asupan zink, magnesium, dan serat dengan kadar gula darah puasa pasien diabetes mellitus tipe 2 di RS PKU Muhammadiyah Temanggung. 
Tujuan dari penelitian ini adalah mengetahui hubungan asupan zink, magnesium, dan serat dengan kadar gula darah puasa pasien diabetes mellitus tipe 2 di RS PKU Muhammadiyah Temanggung.

\section{METODE PENELITIAN}

Penelitian ini merupakan jenis penelitian analitik yaitu penelitian yang ditujukan untuk mengetahui hubungan suatu variabel dengan variabel lainnya. Desain penelitian yang digunakan adalah cross sectional. Data yang dikumpulkan peneliti terdiri dari dua data yaitu data primer dan sekunder. Data primer dalam penelitian ini adalah asupan zink, magnesium, dan serat pasien diabetes mellitus tipe 2 , sedangkan data sekundernya ialah jumlah dan kadar gula darah pasien diabetes mellitus tipe 2 di RS PKU Muhammadiyah Temanggung. Penelitian ini dilakukan pada bulan Desember 2018 Februari 2019 di rumah sakit PKU Muhammadiyah Temanggung dengan populasi 89 pasien sedangkan jumlah sampelnya adalah 45 pasien. Instrumen yang digunakan W adalah form Recall 2x24 jam dan Food Frequency Questionnaire (FFQ), cara pengumpulan data wawancara dengan responden mengenai asupan makanannya selama 2x24 jam serta kebiasaan makan responden. Analisis data menggunakan uji univariat dan bivariat, uji univariat meliputi uji yang digunakan untuk melihat gambaran asupan zink, magnesium, dan serat menggunakan tabel frekuensi, rata-rata, median, standar deviasi, serta nilai maksimal minimal. Sedangkan uji bivariat dilakukan setelah uji normalitas kolmogorov smirnov kemudian dilanjutkan uji korelasi spearman untuk melihat ada hubungan variabel asupan zink, magnesium, dan serat dengan variabel terikat yaitu kadar gula darah puasa pasien diabetes mellitus tipe 2 .

\section{HASIL DAN PEMBAHASAN}

Karakteristik responden berdasarkan umur, jenis kelamin, pendidikan, dan pekerjaan disajikan dalam tabel 1 .

Tabel 1. Karakteristik Responden

\begin{tabular}{lcc}
\hline Karakteristik Responden & n & \% \\
\hline Umur & 6 & \\
$30-49$ & 28 & 13 \\
$50-64$ & 11 & 62 \\
$65-80$ & & 24 \\
Jenis Kelamin & 22 & \\
Laki-laki & 24 & 48 \\
Perempuan & & 53 \\
Pendidikan & 34 & \\
Tamat SD/Sederajat & 3 & 76 \\
Tamat SMP/Sederajat & 3 & 7 \\
Tamat SMA/Sederajat & 5 & 7 \\
Tamat Diploma/Sarjana & & 11 \\
Pekerjaan & 15 & \\
IRT (Ibu Rumah Tangga) & 3 & 33 \\
PNS (Pegawai Negeri Sipil) & 17 & 6 \\
Swasta & 11 & 23 \\
Wiraswasta & & \\
\hline
\end{tabular}


Karakteristik responden berdasarkan umur menunjukkan sebagian besar responden berada pada umur 50-64 tahun dengan persentase $62 \%$, karakteristik responden berdasarkan jenis kelamin menunjukkan sebagian besar responden merupakan perempuan dengan persentase 53\%, karakteristik responden berdasarkan pendidikan menunjukkan responden merupakan tamatan SD/sederajat, karakteristik responden berdasarkan pekerjaan menunjukkan responden sebagian besar merupakan pekerja swasta.

Uji univariat mengenai kadar gula darah puasa, asupan zink, asupan magnesium, dan asupan serat disajikan dalam tabel 2 .

Tabel 2. Uji Univariat

\begin{tabular}{|c|c|c|}
\hline \multicolumn{3}{|r|}{$\%$} \\
\hline \multicolumn{3}{|l|}{ Kadar Gula Darah Puasa } \\
\hline Tidak terkendali $(\geq 126 \mathrm{mg} / \mathrm{dl})$ & 44 & 97 \\
\hline \multicolumn{3}{|l|}{ Terkendali $(<126 \mathrm{mg} / \mathrm{dl})$} \\
\hline \multicolumn{3}{|l|}{ Asupan Zink } \\
\hline \multicolumn{3}{|c|}{ Defisit (<AKG berdasarkan umur \& jenis kelamin) $\quad 45$} \\
\hline \multicolumn{3}{|c|}{ Normal ( $\geq$ AKG berdasarkan umur \& jenis kelamin) $\quad 0 \quad 0$} \\
\hline \multicolumn{3}{|c|}{ Tingkat Kecukupan Zink } \\
\hline Kurang $(<77 \%)$ & 45 & 100 \\
\hline Cukup $(\geq 77 \%)$ & 0 & 0 \\
\hline \multicolumn{3}{|l|}{ Asupan Magnesium } \\
\hline Defisit (<AKG berdasarkan umur \& jenis kelamin) & 45 & 100 \\
\hline Normal ( $\geq \mathrm{AKG}$ berdasarkan umur \& jenis kelamin) & 0 & 0 \\
\hline \multicolumn{3}{|l|}{ Tingkat Kecukupan Magnesium } \\
\hline Kurang $(<77 \%)$ & 38 & 84 \\
\hline Cukup ( $\geq 77 \%)$ & 7 & 16 \\
\hline \multicolumn{3}{|l|}{ Asupan Serat } \\
\hline Defisit (<AKG berdasarkan umur \& jenis kelamin) & 45 & 100 \\
\hline Normal ( $\geq \mathrm{AKG}$ berdasarkan umur \& jenis kelamin) & 0 & 0 \\
\hline \multicolumn{3}{|l|}{ Tingkat Kecukupan Serat } \\
\hline Kurang $(<90 \%)$ & 45 & 100 \\
\hline Cukup (90-119\%) & 0 & 0 \\
\hline
\end{tabular}

Setelah dilakukan analisis univariat didapatkan hasil bahwa kadar gula darah puasa responden sebanyak $97 \%$ berada dalam kategori tidak terkendali, asupan zink responden seluruhnya (100\%) dalam kategori defisit, asupan magnesium responden seluruhnya (100\%), asupan serat responden seluruhnya (100\%) termasuk dalam kategori defisit.

\section{Uji Bivariat}

Hasil analisis mengenai asupan zink dengan kadar gula darah puasa menunjukkan nilai $r=-0,999$ dan $p=0,000(p<0,05)$. Dari hasil terlihat $\mathrm{p}=0,000(<0,05)$ sehingga ada hubungan asupan zink dengan kadar gula darah puasa penderita diabetes mellitus tipe 2 di rumah sakit PKU Muhammadiyah Temanggung dengan arah hubungan negatif dan kekuatan hubungan sangat kuat ditunjukkan dengan nilai $r=-0,999$. Dilihat dari sebaran data ada kecenderungan semakin tinggi asupan zink maka semakin rendah kadar gula darah puasa. Hasil penelitian ini sejalan dengan penelitian yang dilakukan Timimi (2011) mengenai status zink dan diabetes yang berkesimpulan bahwa prevalensi kekurangan zink marginal dijumpai lebih tinggi pada kelompok diabetes. Disamping itu, status zink berkaitan dengan kontrol glikemik diabetes. Hasil 
penelitian lain yang dilakukan Kartika (2016) menyatakan bahwa adanya perbedaan dalam pemberian zink selama 30 hari dengan dosis $5 \mathrm{mg} / \mathrm{kg}$ BB yang lebih baik dari dosis 3 $\mathrm{mg} / \mathrm{kg}$ BB terhadap kadar gua darah, yang berarti semakin banyak asupan zink yang dikonsumsi maka akan menurunkan kejadian glukosa darah tinggi pada pasien diabetes mellitus tipe 2 .

Analisis mengenai asupan magnesium dengan kadar gula darah puasa menunjukkan nilai $r=-0,386$ dan $p=0,009$ $(\mathrm{p}<0,05)$. Dari hasil yang didapatkan terlihat bahwa nilai $\mathrm{p}=0,009(<0,05)$ sehingga dapat disimpulkan ada hubungan yang bermakna asupan magnesium dengan kadar gula darah puasa pada penderita diabetes mellitus tipe 2 di rumah sakit PKU Muhammadiyah Temanggung dengan arah hubungan negatif dan kekuatan hubungan cukup kuat ditunjukkan dengan nilai $r=-0,386$. Dilihat dari sebaran data ada kecenderungan semakin tinggi asupan magnesium makan semakin redah kadar gula darah puasa. Hal ini sejalan dengan penelitian yang dilakukan Faraditha (2014) yang menunjukkan terdapat hubungan asupan magnesium dan kadar glukosa darah puasa. Semakin tinggi asupan magnesium maka semakin menurun kadar glukosa darah puasa. Sales Ch (2006) dalam Sri Yenny
(2011) menyatakan bahwa magnesium sebagai mikromineral yang memegang peranan penting pada homeostatis glukosa dan kerja insulin.

Analisis mengenai asupan serat dengan kadar gula darah puasa menunjukkan nilai $\mathrm{r}=-1$ dan $\mathrm{p}=0,000(\mathrm{p}<0,05)$. Dari hasil didapatkan nilai $\mathrm{p}=0,000(<0,05)$ sehingga dapat disimpulkan ada hubungan antara asupan serat dengan kadar gula darah puasa pada penderita diabetes mellitus tipe 2 di rumah sakit PKU Muhammadiyah Temanggung dengan arah hubungan negatif dan kekuartan hubungan sangat kuat ditunjukkan dengan nilai $r=-1$. Dilihat dari sebaran data ada kecenderungan semakin tinggi asupan serat maka semakin rendah kadar gula darah puasa. Hal ini sejalan dengan penelitian yang dilakukan Bintanah (2012) mengenai serat dan glukosa darah dengan judul asupan serat dengan kadar gula darah, kadar kolesterol total dan status gizi pada pasien diabetes mellitus tipe 2 di rumah sakit roemani semarang menunjukkan hasil ada hubungan asupan serat dengan kadar gula darah. Serupa dengan penelitian yang dilakukan Fitri (2012) dengan judul asupan energi, karbohidrat, serat, beban glikemik, latihan jasmani, dan kadar gula darah pada pasien diabetes mellitus tipe 2 menunjukkan 
hasil adanya hubungan yang bermakna antara serat dengan kadar gula darah pasien diabetes mellitus tipe 2 .

\section{KESIMPULAN DAN SARAN KESIMPULAN}

Kadar gula darah puasa pasien diabetes mellitus tipe 2 di rumah sakit PKU Muhammadiyah Temanggung sebanyak 44 responden (97\%) terdapat dalam kategori tidak terkendali dan 1 responden (3\%) memiliki gula darah puasa yang terkendali. Pasien DM tipe 2 di rumah sakit PKU Muhammadiyah Temanggung memiliki asupan zink, asupan magnesium dan asupan serat yang defisit. Sedangkan untuk tingkat kecukupan asupan zink pasien diabetes mellitus tipe 2 seluruhnya dalam kategori kurang, tingkat kecukupan asupan magnesium pasien diabetes mellitus tipe 2 sebagian besar kurang dengan 38 responden (84\%) 7 responden $(16 \%)$ dalam kategori normal, dan tingkat kecukupan asupan serat pasien diabetes mellitus tipe 2 seluruhnya dalam kategori kurang. Ada hubungan asupan zink dengan kadar gula darah puasa pasien diabetes mellitus tipe 2 , ada hubungan asupan magnesium dengan kadar gula darah puasa pasien diabetes mellitus tipe 2, ada hubungan asupan serat dengan kadar gula darah puasa pasien diabetes mellitus tipe 2 di rumah sakit PKU Muhammadiyah Temanggung.

\section{SARAN}

Pemberian konseling dari ahli gizi secara berkala mengenai asupan zat gizi mikro (zink dan magnesium) dan serat serta kaitannya dengan diabetes mellitus tipe 2 . Diharapkan untuk penderita diabetes mellitus tipe 2 agar mengonsumsi makanan yang mengandung zat gizi zink, magnesium, dan serat serta lebih mengatur pola makannya.

\section{DAFTAR PUSTAKA}

Albertus, Jacobus. 2000. Jurnal Status Mineral Seng ( $\mathrm{Zn})$ dan Magnesium (Mg) Penderita Diabetes Melitus Tipe 2 Dengan Regulasi Gula Darah Baik dan Jelek. Semarang.

Achadi. 2007. Gizi Dan Kesehatan Masyarakat. PT. Raja Grafindo Persada: Jakarta.

Al-Timimi, J.Dhia. 2009. Marginal Zinc Deficiency: A Significant But Unrecognized Public Health Problem In Irac. Duhok Med 2009;3(1):1-3. Iraq

Akhuemokhan, I.K., Eregie, A. dan Fasanmade, O.A. 2013. Diabetes prevention and management: the role of trace minerals. African J. of Diabetes Med., 21: 37-41.

American Diabetes Association. 2015. Standars Of Medical Care In Diabetes 2015, Diabetes Care.

Bintanah, Sufi., Handarsari, Erma. 2012. Asupan Serat Dengan Kadar Gula 
Darah, Kadar Kolesterol Total dan Status Gizi Pada Pasien Ddiabetus Mellitus Tipe 2 di Rumah Sakit Roemani Semarang. Semarang.

Cristiane Hermes Sales, Lucia Fátima Campos Pedrosa, Josivan Gomes Lima, Telma Maria Araújo Moura Lemos, Célia Colli. 2011 Influence Of Magnesium Status And Magnesium Intake On The Blood Glucose Control In Patient Withttype 2 Diabetes. Elsevier Ltd Eur Soc Clin Nutr Metab;

Faraditha, Anggun. 2014. Jurnal Hubungan Asupan Magnesium Dan Kadar Glukosa Darah Puasa Pasien Rawat Jalan Diabetes Mellitus Tipe 2. Malang.

Fitri Dan Wirawanni Y. 2014. Jurnal Hubungan Konsumsi Karbohidrat, Konsumsi Total Energi, Konsumsi Serat, Beban Glikemik Dan Latihan Jasmani Dengan Kadar Glukosa Darah Pada Pasien Diabetes Mellitus Tipe 2. Semarang.

Gibney J.M., Margarett M.B., Kearney M.J., Arab L. 2009. Gizi Kesehatan Masyarakat. Jakarta: Buku Kedokteran EGC;

Kemenkes RI. 2013. Riskesdas Dalam Angka Provinsi Jawa Tengah. Balitbang Kemenkes RI. Jakarta

Kartika, Nadini.,Rachmawati, Banundari., Johan, Andrew. 2016. PengaruhPemberian Zn Terhadap Kadar GlukosaDarahdan Kadar Superoksida Dismutase PadaTikusWistar yang DiinduksiStreptozotocin. Semarang.

Larsson SC, Wolk A. Magnesium Intake And Risk Of Type 2 Diabetes: A Meta-
Analysis. J Intern Med. 2007 Aug; 262(2):208-14

PERKENI. 2015. Pengelolaan Dan Pencegahan Diabetes Mellitus Tipe 2 Di Indonesia. PERKENI. Jakarta.

Sri Yenni, Luh Gede., Suastika, Ketut. 2011. Korelasi Antara Kadar Magnesium dengan Resistensi Insulin Pada Penduduk Suku Bali di Desa Pedawa Kabupaten Bululeleng. Denpasar.

Witasari, Ucik., Rahmawaty, Setyaningrum., Zulaekah, Siti. 2009. Jurnal Hubungan Pengetahuan, Asupan Karbohidrat, dan Serat dengan Pengendalian Kadar Glukosa Darah Pada Penderita Diabetes Mellitus Tipe 2. Surakarta.

World Health Organization. 2006. Definition and Diagnosis of Diabetes Mellitus Intermediate Hyperglikemia. WHO Document Production Services. Geneva, Switzerland.

Yiqing Song, Qi Dai, Ka He. 2013. Magnesium Intake, Insulin Resistance, And Type 2 Diabetes. North Am J Med Sci. Jan; 6:9-15. 